\title{
Biomarkers in Cardiac Surgery
}

\author{
Cem Çil ${ }^{a} \quad$ Funda Sungur Biteker ${ }^{b}$ Oğuzhan Çelik ${ }^{a} \quad$ Bülent Özlek $^{a} \quad$ Eda Özlek $^{a}$ \\ Aysel Gökçek $^{\mathrm{a}}$ Volkan Doğan ${ }^{\mathrm{a}}$

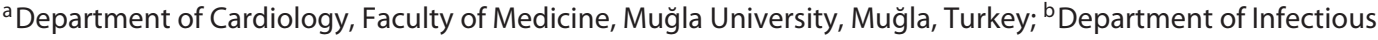 \\ Diseases and Clinical Microbiology, Yatağan State Hospital, Muğla, Turkey
}

Dear Editor,

We read with great interest the article by Clementi et al. [1] published in your journal. The authors investigated the predictive value of presepsin and procalcitonin levels for the development of adverse postoperative complications and mortality in patients undergoing cardiac surgery. The results of this study showed that presepsin and procalcitonin levels were significantly higher in patients with adverse renal and respiratory outcomes. The presepsin levels were significantly higher in patients with adverse cardiovascular outcome and the procalcitonin values in patients with sepsis. The authors concluded that presepsin, measured $48 \mathrm{~h}$ after the procedure, was a better prognostic marker compared to procalcitonin for adverse cardiovascular outcomes in cardiac surgery patients.

We congratulate the authors for their interesting study but we would like to raise some concerns regarding biomarkers in patients undergoing cardiac surgery. Although numerous publications deal with the diagnostic and prognostic values of biomarkers in cardiac surgical settings, there is still a need for markers with sufficient predictive value, especially with regard to short-term prognosis. The most widely used and investigated biomarkers are C-reactive protein (CRP), troponin, B-type natriuretic peptide (BNP), and N-terminal pro-BNP (Nt-pro-BNP). Eikvar et al. [2] compared post-surgery levels of cardiac markers in groups of patients who suffered from postoperative myocardial infarction and those who did not. The first postoperative day patients with postoperative myocardial infarction had higher levels of serum troponin T and CK-MB compared to those who did not suffer from an infarction [2]. Gasparovic et al. [3] showed that preopera- tive and postoperative NT-pro-BNP as well as troponin $\mathrm{T}$ values were significantly higher in patients who subsequently developed atrial fibrillation after cardiac surgery, while CRP did not seem to be influential.

Due to their universal availability and fairly straight forward interpretation of values, $\mathrm{CRP}$, troponin, and $\mathrm{BNP} / \mathrm{Nt}$-pro$\mathrm{BNP}$ are still the most common biomarkers used worldwide in all cardiac surgery patients. However, presepsin and procalcitonin are still not widely available on common laboratory platforms and in most of the hospitals. Therefore, we would be grateful if the authors have and would provide the data regarding the prognostic significance of troponin, BNP, and CRP levels and their association with presepsin and procalcitonin levels for the development of postoperative adverse events in cardiac surgery patients.

\section{References}

1 Clementi A, Virzì GM, Muciño-Bermejo MJ, Nalesso F, Giavarina D, Carta M, et al: Presepsin and procalcitonin levels as markers of adverse postoperative complications and mortality in cardiac surgery patients. Blood Purif 2018:1-9.
2 Eikvar L, Pillgram-Larsen J, Skjaeggestad O, Arnesen H, Stromme JH: Serum cardio-specific troponin $\mathrm{T}$ after open heart surgery in patients with and without perioperative myocardial infarction. Scand J Clin Lab Invest 1994;54:329-335.
3 Gasparovic H, Burcar I, Kopjar T, Vojkovic J, Gabelica R, Biocina B, et al: NT-pro-BNP, but not $\mathrm{C}$-reactive protein, is predictive of atrial fibrillation in patients undergoing coronary artery bypass surgery. Eur J Cardiothorac Surg 2010;37:100-105.

\section{KARGER}

(c) 2018 S. Karger AG, Basel

E-Mail karger@karger.com

www.karger.com/bpu
Cem Cil, MD

Mugla Sitki Kocman Universitesi Tip Fakultesi

Orhaniye Mahllesi, Haluk Özsoy Cad.

TR-48000 Muğla (Turkey)

E-Maildrcemcil@yahoo.com 